\title{
Impact of the Conservation of Iroko (Miliciaexcelsa (Welw.) C.C. Berg, Moraceae) on the Fertility of Cocoa-growing Soils in Agroforests of Djèkro (Center-West, Côte d'Ivoire)
}

\author{
Akedrin Tetchi Nicaise ${ }^{1, ~ *}$, Akotto Odi Faustin ${ }^{2}$, Kouassi Kouadio Claude ${ }^{1}$ \\ ${ }^{1}$ Agricultural Production Improvement Laboratory, UFR of Agroforesterie, Jean Lorougnon Guédé University, Daloa, Côte d'Ivoire \\ ${ }^{2}$ Department of Soil, Water and Geomaterials Sciences, UFR of Earth Sciences and Mineral Resources, Félix Houphouët-Boigny University, \\ Abidjan, Côte d'Ivoire
}

Email address:

akedrinick@yahoo.fr (A. T. Nicaise)

${ }^{*}$ Corresponding author

To cite this article:

Akedrin Tetchi Nicaise, Akotto Odi Faustin, Kouassi Kouadio Claude. Impact of the Conservation of Iroko (Miliciaexcelsa (Welw.) C.C. Berg, Moraceae) on the Fertility of Cocoa-growing Soils in Agroforests of Djèkro (Center-West, Côte d'Ivoire). American Journal of Agriculture and Forestry. Vol. 8, No. 4, 2020, pp. 137-143. doi: 10.11648/j.ajaf.20200804.17

Received: June 22, 2020; Accepted: July 14, 2020; Published: July 28, 2020

\begin{abstract}
The present study aims to determine the spatial gradient of organic matter in soil-litter mixtures as a function of the distance to iroko associated with cocoa trees. The demonstration of the preservation of iroko is carried out thanks to a floristic inventory and a survey ethnobotany from 323 farmers. The fertility of cocoa-growing soils was estimated using spatial organic matter measurement in 12 cocoa plantations of 1,5 to 2 ha associated with iroko. A total of 48 composite litter samples were collected at $20 \mathrm{~cm}$ along the spatial gradient of the iroko at distances of 1-2 m, 2-4 $\mathrm{m}$ and 4-6,5 $\mathrm{m}$ and then in the control (without iroko). With $73 \%$ of citation, populations are favorable to its preservation in cocoa agroforests. Prized for its artisanal and medicinal uses, it improves soil fertility outside the shade provided to cocoa trees. Its average organic matter content in cocoa-growing soils is very significant. The spatial gradient of $M$. excelsa has had a significant impact on the amount of organic matter less than $6 \%$ in the iroko rhizosphere while it reaches 6 to $8 \%$ in cocoa trees. Its preservation in cocoa trees contributes to improving the properties of poor soils. However, differential processes ultimately affect the decomposition rates of organic matter, hence the separation of cocoa trees by at least $10 \mathrm{~m}$ to benefit from the supply of carbon, nitrogen and phosphorus ions.
\end{abstract}

Keywords: Agroforestry, Milicia excelsa, Cocoa Farming, Soil Fertility, Côte d'Ivoire

\section{Introduction}

In the past, we tore trees from plots to have more areas cultivable. Nowadays, soils are eroded, biodiversity is declining, yields have stagnated and insect pests are increasingly resistant to pesticides. It is necessary to apply an agro-ecological transition of agriculture which involves an increase in biological diversity and the intensification of ecological interactions between the biophysical components of ecosystems which promote fertility, productivity and resilience in the face external disturbances [1,2].

The association of trees with cocoa trees is an innovative technique, which is part of agroforestry. It is described as sustainable and economically profitable by several authors such as [3] and [4]. In this context, the association of trees with crops appears to be a promising system which structures time and space, biotic and abiotic interactions and maintains soil fertility. Thus, agroforestry systems could lead to increased functional resilience to climate change $[5,6]$.

They are also described as being able to favor a wide range of ecosystem services including those associated with underground biotic interactions such as carbon sequestration [7]. Authors such as [8, 9] and [10] reported that many species associated with cocoa trees play an important role in the functioning of cocoa plantations, mainly due to the maintenance of organic matter (OM) which is one of the characteristics of soils that can be linked to soil fertility. 
Indeed, organic matter in soils constitutes an essential compartment of the biogeochemical carbon cycle [11, 12]. To guarantee the economic performance of cocoa plantations, it is essential to master the relationships between the woody trees used in agroforestry and the fertility of the soil. Therefore, maintaining the fertility of cocoa-growing soils can be ensured by species like Milicia excelsa, in the sense that its morphology is linked to a set of physical factors (soil structure, porosity...), chemical ( $\mathrm{pH}, \mathrm{CEC} . .$.$) whose influence$ on the dynamics of organic matter is proven [13].

The hypothesis put forward here is that there would be a spatial gradient of organic matter in cocoa-growing soils as a function of the distance of the iroko (Milicia excelsa), companion of the cocoa tree in Djèkro (Center-West, Côte d'Ivoire). In Côte d'Ivoire, despite the knowledge that the populations have on the impact of trees, in particular on the humidity and the maintenance of the fertility of soilcultivated crops $[14,15,16]$, the literature currently available on the variability of organic matter as a function of distance from the associated tree is limited.

This work aims to contribute to the characterization of the dynamics of organic matter in the soil along an iroko spatial gradient, in comparison with that of a control. To do this, an assessment of the floristic diversity of cocoa-cultivated soils, still little studied is necessary. The objective of this work is to characterize the sites of a dozen traditional cocoa plantations in Djèkro both in terms of the companion forest species of the cocoa tree and the spatial gradient of organic matter in cocoa-cultivated soils according to the remoteness of iroko. It will involve carrying out an inventory of floristic data on potential study sites and also characterizing organic matter on the surface horizon along a spatial gradient of iroko from the analysis of soil samples taken.

\section{Materials and Methods}

\subsection{Study Site}

Djèkro is located in the Center-West of Côte d'Ivoire between $06^{\circ} 51^{\prime}$ and $06^{\circ} 59^{\prime}$ north latitude and $06^{\circ} 36$ and $06^{\circ} 44^{\prime}$ West longitude (Figure 1), in the administrative region of Haut-Sassandra of which Daloa is the capital. The relief of the region is quite diverse and very little hilly; the altitude varies between 500 and 800 meters. The climate is the equatorial type with 4 seasons. The average temperature fluctuates between 22 and $26^{\circ} \mathrm{C}$. The average annual rainfall is $1500 \mathrm{~mm}$. Djèkro benefits from excellent humidity and good hygrometry. The vegetation is dominated by the families of Sterculiaceae and Ulmaceae. The soils of the area are mostly FerricAcrisol, clay-sandy or clay-loam that is generally found in cocoa trees with places the presence of Gleysols soils (hydromorphic soils) encountered in the shallows, rich in organic matter [17]. This site was chosen because Daloa is one of the main cocoa producing regions in Côte d'Ivoire.

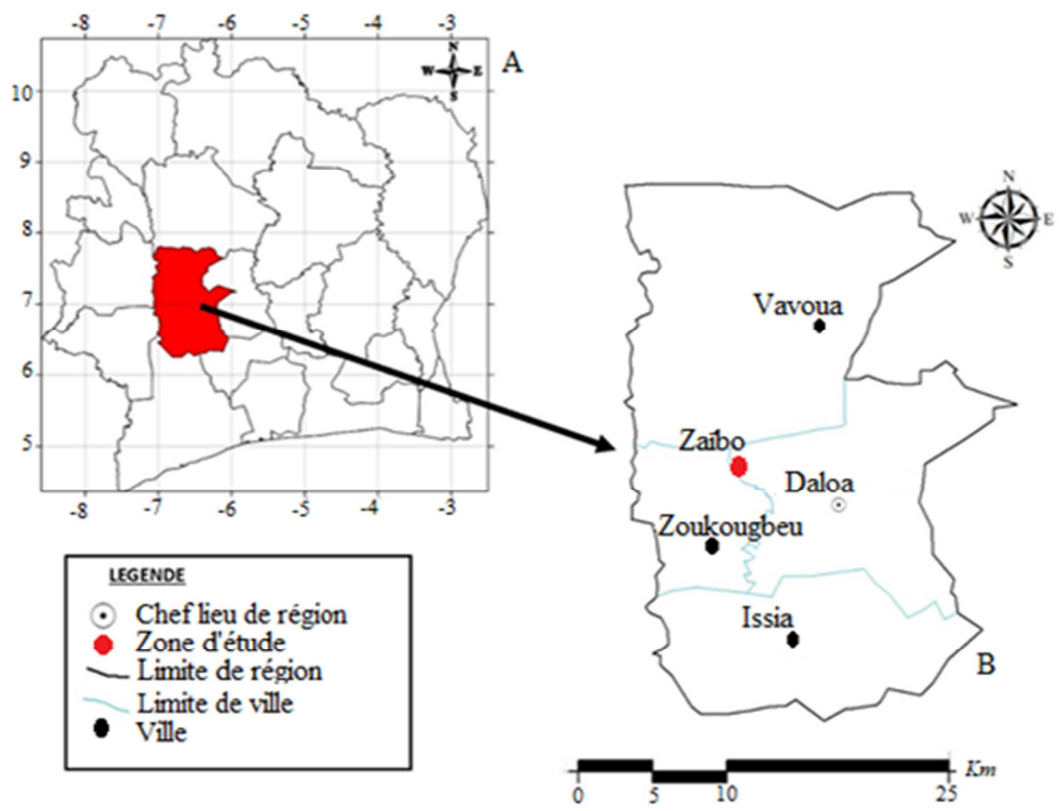

Figure 1. Location of the study area. A: Administrative division of Côte d'Ivoire; B: Haut-Sassandra region and study area.

\subsection{Evaluation of Agroforestry Practices in a Producing Environment}

Semi-structured interviews and direct and participating observations were used to briefly describe the practices of agroforestry in rural areas with 323 identified referent farmers [18]:

$$
\mathrm{n}=\frac{U_{1-\alpha / 2}^{2} x p(1-p)}{d^{2}} \text { cocoa producers }
$$

$\mathrm{n}=$ sample size; $U_{1-\alpha / 2}^{2}=1,96$ is the value of the normal random variable for a probability value $\alpha=0,05 ; p$ corresponds to the proportion of individuals who know the species and make at least one use of it; $d$ is the standard error, expressed in decimal $(0,05)$. The data collected related to the age and area sown, the variety cultivated, the duration of cultivation, the type and texture of the soil then the characteristics of cocoa-cultivated agroforests (diversity and richness in flora, qualitative diversity of cocoa plantations, 
species used by cocoa farmers as an agroforestry species on their poor soils).

Specimens of species not identified in the field were identified in the Jean Lorougnon Guédé University of Daloa herbarium by comparison with the reference samples [19]. The main biological types have been distinguished according to the work of [19] based on the adaptation of the terminal buds of plants during the bad season. The types of phytogeographic distribution were established based on the large chorological subdivisions of [20].

The organic carbon content (Corg) of cocoa-cultivated soils as a function of the distance to the Iroko tree (Milicia excelsa), was measured in 12 agroforests of approximately 2 ha. The distance to the tree (in $\mathrm{m}$ ) is measured following a spatial gradient perpendicular to the tree $(1-2 \mathrm{~m} ; 2-4 \mathrm{~m} ; 4-6$, $5 \mathrm{~m})$ as well as in the agricultural witness (without Iroko) located nearby. Six samples of a soil-litter mixture of about $1,5 \mathrm{~kg}$ mass per sample and per cocoa tree were taken using an auger at a depth of $20 \mathrm{~cm}$. A composite soil sample was carried out for each of the 12 cocoa plantations as well as on the agricultural control.

In total, 48 soil samples were first dried in the open air for a week, then crushed in porcelain mortar and finally sieved to $2 \mathrm{~mm}$ and bagged for chemical carbon analysis according to standard methods. The organic matter (OM) content is determined by the product of the percentage of carbon in the soil and the conversion factor and the constant 1,724 through:

$$
\mathrm{OM}=\% \operatorname{Corg} \times 1,724
$$

For the interpretation of the OM content, the grouping was done in three classes distributed as follows: (i) high organic matter content $+1,5 \%$ OM (ii) average organic matter content between 1 and 1,5\% of MO (iii) low organic matter content, less than $1 \%$ of OM.

\subsection{Data Processing}

The data collected for the evaluation of fertilization practices in the middle producer were subjected to the method of synthesis of thematic content for qualitative data and to descriptive statistics which made it possible to calculate the proportions, means and standard deviations of quantitative data thanks to the software [21] and the [22]. The variable means were compared using the Tukey test at probability threshold $\mathrm{p}<5 \%$.

\section{Results}

\subsection{Local Perceptions on the Preservation of Forest Species, Accompanying Cocoa Trees}

\subsubsection{Description of the Operations and Characteristics of Cocoa-cultivated Agroforests}

The age of the producers varied from 20 to 95 years with an average of $38 \pm 10$ years (Figure 2). This analysis shows that knowledge of cocoa farming in populations seems to be strongly held by adults without distinction of sex category. The average area sown was $0,4 \pm 0,2$ hectares on soils of sandyclay or sandy texture - silter cultivated for an average of $10 \pm 3$ years. The most cultivated variety is the local "ToutVenant" whose area sown represents approximately $80 \%$ of the total sown against $20 \%$ for the improved variety "Mercedes".

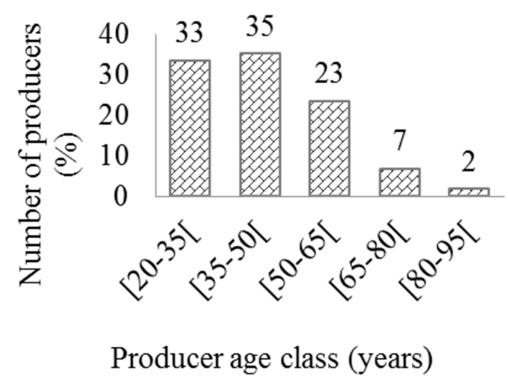

Figure 2. Distribution of producers by age class in the locality of Djèkro.

\subsubsection{Floristic Richness and Qualitative Diversity of Cocoa Plantations}

The floristic inventory carried out made it possible to identify 42 plant species (without the cocoa tree) divided into 38 genera and 27 families. Five families out of the 27, that is $41 \%$ of the total species each contain more than $5 \%$ of the listed species. They are represented by the Moraceae $(11,4 \%)$, Sterculiaceae (9\%), Euphorbiaceae, Apocynaceae and Anacardiaceae, with $6,8 \%$ of the species each. The term "other" represents the 22 other families which each have less than $5 \%$ of the species listed (Figures 3 and 4 ). The study carried out therefore made it possible to establish that the populations have an acute knowledge of the forest species companions of the cocoa tree and that they are to a certain extent favorable to their preservation in agrosystems.

As for the qualitative diversity of cocoa plantations, Microphanerophytes (mp) and Megaphanerophytes (MP) constitute the dominant biological types respectively with $54,76 \%$ and 21,43\%. The Mesophanerophytes (mP) 18,6\%, the Lianescent Mesophanerophytes (LmP) 2,38\% and the Epiphytic Microphanerophytes (mp, EP) 2,38\%) complete the list of Biological Types (Figure 5).

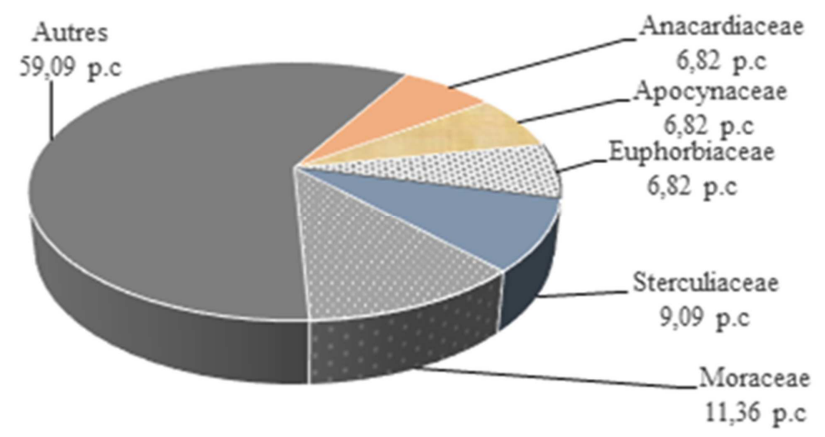

Figure 3. Distribution of families with more than 5\% of the total species of cocoa trees in Djèkro. 

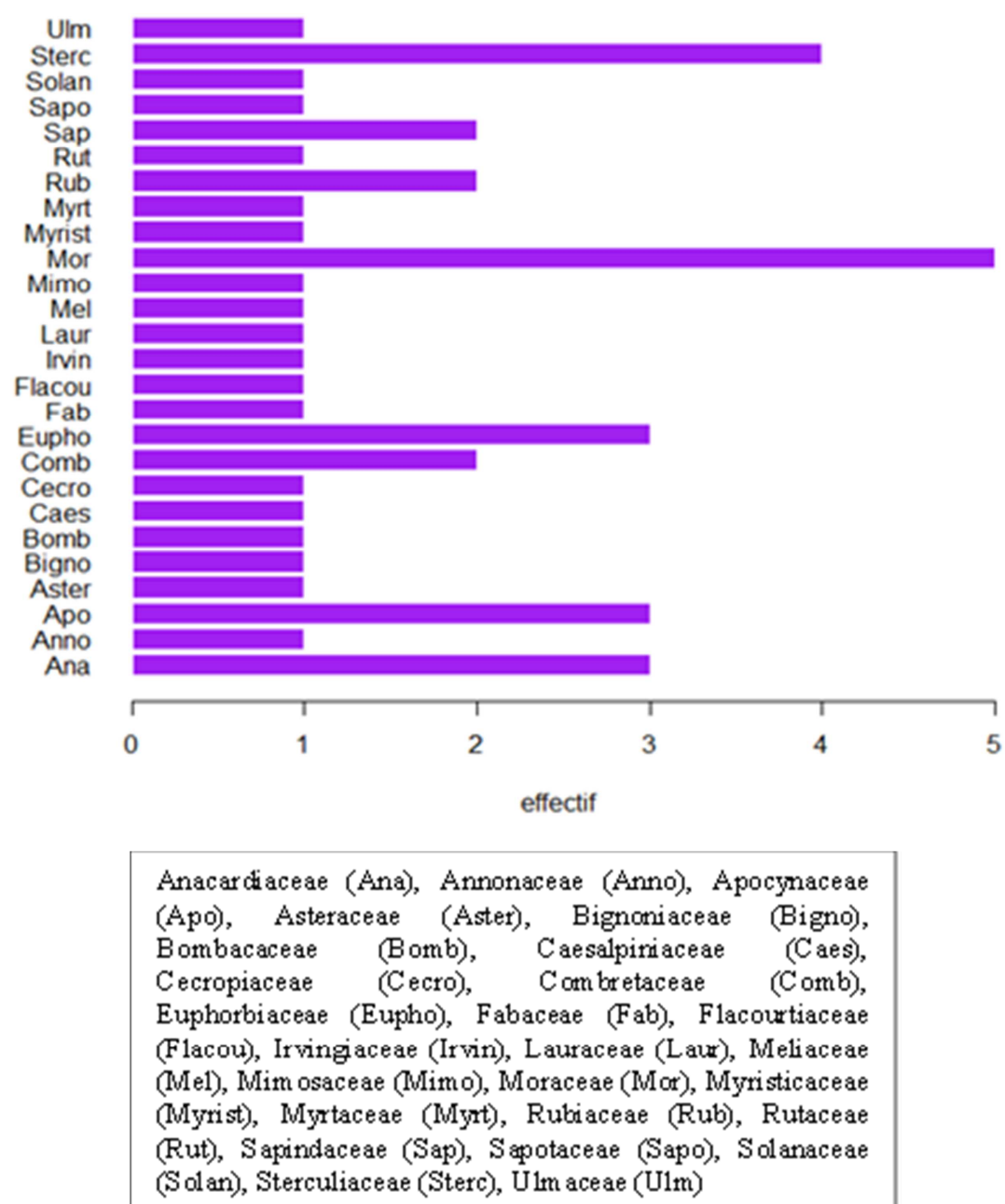

Figure 4. Dominant families of cocoa farms in Djèkro.

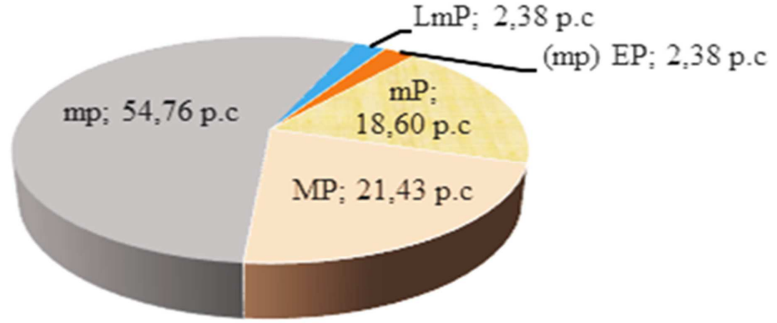

Figure 5. Proportion of flora most represented in Biological types of cocoa plantations studied: $m p$ - Microphanérophytes; $m P$-Mésophanérophytes; MP-Mégaphanérophytes.

\subsubsection{Social Reasons for the Preservation of Milicia Excelsa in Cocoa Plantations}

Local perceptions on the preservation of agroforestry species on depleted cocoa soils have highlighted a certain number of species, the five most frequent of which are recorded in Table 1. Of all the species inventoried in the various cocoa agroforests, Milicia excelsa with 73\% of citation, is the most appreciated species. The study made it possible to establish that the populations are to a certain extent favorable to the preservation of this species in agrosystems.
Knowledge of Milicia excelsa in populations seems to be strongly held by adults without distinction of sex categories (confers distribution of producers by age class). However, the needs for domestication and / or introduction of this species (Figure 6) within populations seem to be strongly held by men with a significant link between the responses of men and those of women ( $p$-value $<0,0043)$.

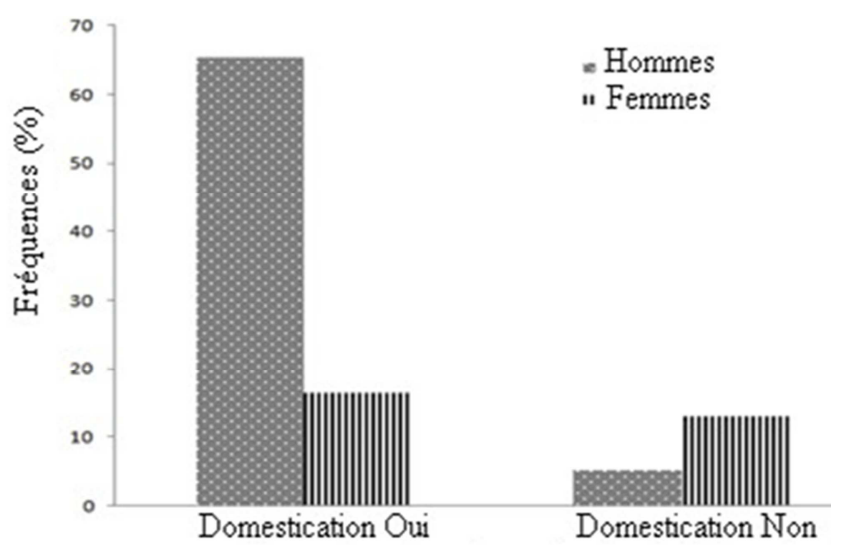

Figure 6. Social reasons for the preservation of Milicia excelsa in cocoa plantations. 
Table 1. Summary list of species used by cocoa farmers as a species of agroforestry on their poor soils from Djèkro.

\begin{tabular}{ll}
\hline Scientific name & Frequency (\%) \\
\hline Miliciaexcelsa (Welw.) C. C. Berg (Moraceae) & 73 \\
Terminaliasuperba Eng I. \& Diels (Combretaceae) & 62 \\
Ricinodendronheudelotii (Baill.) Pierreex Heckel (Euphorbiaceae) & 23 \\
Entandrophragmaangolense (Welw.) C. DC. (Meliaceae) & 20 \\
Terminaliaivorensis A. Chev. (Combretaceae) & 20 \\
\hline
\end{tabular}

\subsection{Contribution of Milicia Excelsa to the Fertility of Cultivated Cocoa Soils}

The organic matter content of cocoa-growing soils differs very significantly depending on the distance from Milicia excelsa ( $\mathrm{P}<0,0001)$. It varies according to an increasing gradient observed from the proximity of the tree and where the roots of $M$. excelsa (2-6\%) to the ends or out of the roots (more than 6\%). This content does not vary significantly in the first categories. On the other hand, without access or access to the roots, where the cocoa trees are located, the concentration of organic matter is very high (Figure 7). The levels of organic matter are significantly higher under the cocoa plantations in companion of $M$. excelsa in comparison of the control (Figure 7).

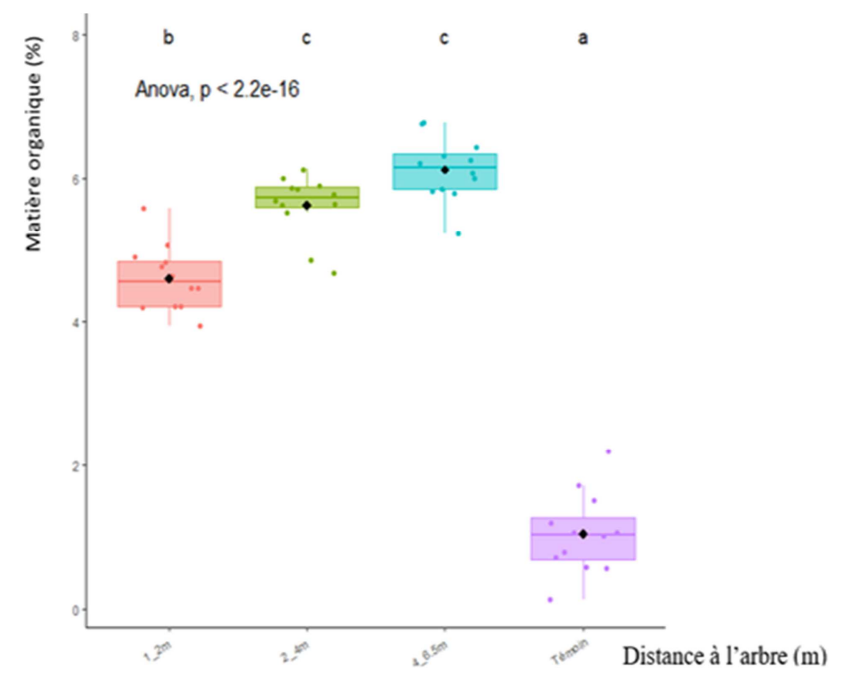

Figure 7. Organic matter content of cocoa-growing soils as a function of the distance from the iroko tree (Milicia excelsa) in the study vineyard in westcentral Cote d'Ivoire.

\section{Discussion}

The highlighting of local perceptions on the preservation of trees in cocoa plantations and its ethnobotanical evaluation constitutes a draft in the long process of domestication of woody tree species. It contributes to a better understanding of the species in general and of the use of certain better-valued species such as iroko (M. excelsa) by cocoa farmers in Djèkro (CenterWest of the Ivory Coast). In fact, in the inventoried agroforests, M. excelsa with $73 \%$ of quotation, remains the main request of the populations to accompany the cocoa tree.

The study conducted established that the populations are to a certain extent favorable to the preservation of iroko in agrosystems mainly because of the endogenous knowledge they have of it. Thus, the fact that knowledge of forest species in general and of iroko, in particular, seems to be strongly held by adults regardless of gender, does not bode well for $M$. excelsa, because of generation generation the same threats will weigh on the organs of the species, when we know that life expectancy tends to decline.

The species remains very much in demand by populations, especially for its multiple uses: crafts, medicine, culture, hygiene and others. Our results join in those of [23] which classifies $M$. excelsa among the species considered as threatened with extinction of the Ivorian flora. On the botanical composition of cocoa plantations, $M$. excelsa is poorly represented. The low presence of this endangered species is due to anthropogenic disturbances in the vegetation of Djèkro. Similar results have been reported by [24, 25], respectively in the Center-West and North-West of the Ivory Coast. M. excelsa has shown greater adaptability to agroforestry systems. Specifically, it appears that $M$. excelsa and Terminalia superba are more suitable for agroforestry than other species such as Ricinodendron heudelotii, Entandrophragma angolense and Terminalia ivorensis. The ability of Milicia excelsa to improve the properties of poor soils is very well known by adult populations and promotes the establishment of mixed cultivation Milicia - Theobroma. With regard to the fertility of cocoa-cultivated soils under agroforest, convergence has been noted in the scientific community on the nature of the correlation between agroforestry and the clay-humus complex composed of humus and litter. Some authors like [26] argue that morphological and biochemical changes in humus and litter enrich the soil with minerals such as: $\mathrm{PO}_{4}{ }^{3-}, \mathrm{NO}^{3-}, \mathrm{K}^{+}, \mathrm{H}^{+}$, $\mathrm{Ca}^{2+}, \mathrm{Fe}^{2+}, \mathrm{Mg}^{2+}$.

Unlike others such as [27] reported that overhead and underground litter represent the main contribution of organic matter to the soil and the major resource for soil organisms. In addition to the minerals provided, agroforest also helps limit the evaporation of water from the soil $[28,29]$. To illustrate this interest of agroforestry compared to the present study, the results report the spatial gradient of $M$. excelsa companion of cocoa trees, has had a significant impact on the total amount of organic matter in the soil surface horizon. There is less than $6 \%$ of organic matter when approaching the iroko tree and where present the roots, while the organic matter concentration reaches $8 \%$, where the cocoa trees are. These results are explained by a differential decomposition of the litter along the gradient: 1-2m; 2-4 $\mathrm{m} ; 4-6,5 \mathrm{~m}$ compared to $M$. excelsa. These functional differences are due to excretions from different extracellular enzymes by soil microorganisms (bacteria and fungi in particular) as reported by [30].

These differential processes ultimately affect the rates of decomposition and the availability of nitrogen $(\mathrm{N})$ and phosphorus (P) as previously demonstrated [31, 32]. An 
interest in the study of agroforestry is the decomposition of these litters which is an essential process which determines the transfers / transformations and fluxes of the elements of the cycles of carbon $(\mathrm{C})$, nitrogen $(\mathrm{N})$ and phosphorus $(\mathrm{P})$ at the soil-plant interface [33]. This shows that cocoa trees have easy access to the nitrate ions present in organic matter and that the tree will have consumed the minerals available to it. Our results are in agreement with those of [7] and [34] who in their development work, recommend a separation of trees of $25 \mathrm{~m}$ allowing to have a culture, between each tree, supplied with nitrate ions.

\section{Conclusion}

The identification of local perceptions on the preservation of forest species in cocoa trees and the botanical evaluation constitute a draft in the long process of domestication of the species. Knowledge of cocoa farming in Djèkro is held by adults aged $38 \pm 10$ who mainly cultivate the local variety "ToutVenant" in association with woody plants other than cocoa.

The inventory of these woody plants counted 42 plant species divided into 38 genera and 27 families. The Moraceae, Sterculiaceae, Euphorbiaceae, Apocynaceae and Anacardiaceae contain $41 \%$ of the listed species, of which $76.13 \%$ are Phanerophytes with Milicia excelsa as the most frequent species on all the sites surveyed.

It can therefore be understood that the populations surveyed have a good knowledge of forest species and that they are favorable to their preservation, according to their multiple uses, in agrosystems. Traditional agroforestry systems, by preserving $M$. excelsa in cocoa plantations, increase the litter (organic matter) returned to the soil according to a spatial gradient that extends from the tree to the cultivated area. This differential process determines the transfers and fluxes of the elements of the carbon, nitrogen and phosphorus cycles at the soil-plant interface.

These results challenge us that there is a need to raise awareness among the population about the introduction of Phanéphyte woody plants into new perennial crops like the cashew tree generally installed on poor soil in the North of Côte d'Ivoire. Also, it is necessary to sensitize the cocoa farmers that one does not need to completely cut down the existing forest to install its cultivation.

\section{References}

[1] Duru D. M., Therond, O., Fares, M. 2015. Designing agroecological transitions; A review. Agron. Sustain. Dev. 35. $1237-1257 \mathrm{p}$.

[2] Duru, M., Therond, O. 2014. Livestock system sustainability and resilience in intensive production zones: which form of ecological modernization? Reg Environ Chang.

[3] Nair, P. K. R. 2007. The Coming of Age of Agroforestry. J. of Sci. of Food \& Ag. 87: 1613-1619p.

[4] Valentini, G. S. 2007. Evaluation de la séquestration du carbone dans des plantations agroforestières et des jachères issues d'une agriculture migratoire dans les territoires autochtones de Talamanca, au Costa Rica. Mémoire de Maitrise, Faculté des Sciences de l'Agriculture et de l'Alimentation, Université de Laval. Quebec. 88 p.

[5] Sylvester, O. 2019. Achieving Food Security in the Face of Inequity, Climate Change, and Conflict, The Difficult Task of Peace, 13: 277-295p.

[6] Adamczewska-Sowińska, K., Sowiński, J. 2019. Polyculture Management: A Crucial System for Sustainable Agriculture Development, Soil Health Restoration and Management, 279319 p.

[7] Cardinael, R. 2017. Stockage de carbone et dynamique des matières organiques des sols en agroforesterie sous climat méditerranéen et tempéré. Thèse de Doctorat de l'Université Paris Saclay, 266p.

[8] Mollet, M., Téré, H., Herzog, F. 2000. Ligneux à usages multiples dans les systèmes agraires tropicaux: une étude de cas de Côte d'Ivoire. Schweiz. Z. Forstwes. 151: 355-364p.

[9] Azonkponon, N. 2001. Conservation in situ de l'Iroko (Milicia excelsa W. C. Berg) dans l'aire culturelle vodoun au Bénin. Mém. de DESS, Université d'Abomey-Calavi, Bénin, 107 p.

[10] Tabuti, J. R. S. 2007. The uses, local perceptions and ecological status of 16 woody species of Gadnumire Subcounty, Uganda. Biodivers. Conserv. 16: 1901-1915p.

[11] Jobbagy, E. G., Jackson, R. B. 2000. The vertical distribution of soil organic carbon and its relation to climate and vegetation. Ecological Applications 10: 423-436p.

[12] Chabbi, A., Cellier, P., Rumpel, C., Gastal, F., Lemaire, G. 2012. Cycle du carbone et risques environnementaux dans les écosystèmes prairiaux. Innovations Agronomiques 22: 17-30p.

[13] Ouinsavi, C., Sokpon, N. 2010. Morphological variation and ecological structure of Iroko (Milicia excels Welw. C. C. Berg) populations across different biogeographical zones in Benin. International Journal of Forestry Research. 8: 10p.

[14] Tano, M. A. 2012. Crise cacaoyère et stratégies des producteurs de la sous-préfecture de Méadji au Sud-ouest ivoirien. Thèse de Doctorat, Université Toulouse le MirailToulouse II, France, 263 p.

[15] Kpangui, K. B., Kouamé, D., Gone, B. Z. B., Vroh, B. T. A., Koffi, B. J. C., Adou, Y. C. 2015. Typology of cocoa-based agroforestry systems in a forest-savannah transition zone: case study of Kokoumbo (Centre, Côte d'Ivoire). International Journal of Agronomy and Agricultural Research (IJAAR) $6 \mathrm{~N}^{\circ}$ 3: $36-47 \mathrm{p}$.

[16] Adou, Y. C., Kpangui, K. B., Vroh, B. T. A., Ouattara, D. 2016. Pratiques culturales, valeurs d'usage et perception des paysans des espèces compagnes du cacaoyer dans des agroforêts traditionnelles au centre de la Côte d'Ivoire. Revue d'ethnoécologie, 9, 2016, 24-74p.

[17] N'guessan, K. J-C., Akotto, O. F., Snoeck, D., Camara, M., Yao-Kouamé, A. 2016. Potentiel de fertilité chimique des vergers de cacaoyer Theobroma cacao L. (Malvaceae) en Côte d'Ivoire. IJIAS, 18 (3): 868-879p.

[18] Dagnélie, P. 2008. Le plan d'expérience évolue. Faculté universitaire des Sciences agronomiques, Gembloux (Belgique Revue MODULAD, $\mathrm{N}^{\circ} 38.24$ p. 
[19] Ake, A. 2001-2002. Flore de la Côte d'Ivoire 1, catalogue, systématique, biogeography et écologie. Suisse: Conservatoire et jardin Botanique de Genève; Boissiera 57, 396p.

[20] White, F. 1986. La végétation de l'Afrique. Mémoire accompagnant la carte de végétation de l'Afrique UNESCO /AETFAT/UNSO. ORSTOM et UNESCO. Paris, collection Recherches sur les Ressources Naturelles, 20: 1-384p.

[21] Core, R., Team, R. 2019. A Language and Environment for Statistical Computing, $\mathrm{R}$ Foundation for Statistical Computing, Vienna, Austria 2019.

[22] Studio, R., Team, RStudio. 2018. Integrated Development Environment for R, RStudio, Inc., Boston.

[23] UICN. 2015. IUCN Red List of Threatened Species. Version 2015.1.

[24] Ouattara, D., Kouamé, D., Tiébré, M. S., Cissé, A., N'Guessan, K. E. 2016. Diversité floristique et usages des plantes dans la zone soudanienne du Nord-ouest de la Côte d'Ivoire. Journal of Animal and Plant Sciences, 31 (1): 48154830p.

[25] Ouattara, D., Vroh, B. T. A., Kpangui, K. B., N'Guessan, K. E. 2013. Diversité végétale et valeur pour la conservation de la réserve botanique d'Agbaou en création, Centre-ouest, Côte d'Ivoire. Journal ofAnimal and Plant Sciences, 20 (1): 30343047 p.

[26] Gavaland, A., Burnel, L. 2005. Croissance et biomasse aérienne de noyers noirs en parcelle agroforestière; Rapport du WP3 + annexes, Projet européen SAFE, 5p.

[27] Bais, H. P., Weir, T. L., Perry, L. G., Gilroy, S., Vivanco, J. M. 2006. The Role of Root Exudates in Rhizosphere Interactions with Plants and Other Organisms. Annual Review of Plant Biology 57, 233-266p.
[28] Palma, J. H. N., Oliveira, T. S., Crous-Duran, J., Paulo, J. A. 2016. Using Yield-SAFE model to assess hypothetical eucalyptus silvopastoral systems in Portugal in 3rd European Agroforestry Conference Book of Abstracts. Gosme M et al. (eds.). European Agroforestry Federation, Montpellier. 348$351 \mathrm{p}$.

[29] Béral, C., Andueza, D., Ginane, C., Bernard, M., Liagre, F., Girardin, N., Emile, J-C., Novak, S., Grandgirard, D., Deiss, V., Bizeray, D., Thiery, M., Rocher, A. 2018. Agroforesterie en système d'élevage ovin: étude de son potentiel dans le cadre de l'adaptation au changement climatique. $158 \mathrm{p}$.

[30] Bertrand, I., Chabbert, B., Kurek, B., Recous, S., 2006. Can the Biochemical Features and Histology of Wheat Residues Explain their Decomposition in Soil? Plant and Soil 281: 291$307 \mathrm{p}$.

[31] Betencourt, E. 2012. Interactions entre céréale et légumineuse en association et acquisition de phosphore du sol: processus rhizosphériques sous-jacents. PhD. CIRAD, Montpellier SupAgro, France.

[32] Nandjui, J., Voko, D. R. R., Kouadio, A. N. M. S., Fotso, B., Tano, Y., Zeze, A. 2013. Assessment of the occurrence and abundance of mycorrhizal fungal communities in soils from yam (Dioscorea spp.) cropping fields in Dabakala, North Côte d'Ivoire. African Journal of Agricultural Research 8 (44): 5572-5584p.

[33] Wardle, D. A., Bardgett, R. D., Klironomos, J. N., Setälä, H., Putten, W. H., Wall, D. H. 2004. Ecological Linkages Between Aboveground and Belowground Biota. Science 304, 16291633p.

[34] Amosse, J., Turberg, P., Kohler-Milleret, R., Gobat, J. M., Le Bayon, R. C. 2015. Effects of endogeic earthworms on the soil organic matter dynamics and the soil structure in urban and alluvial soil materials. Geoderma 243-244, 50-57p. 